\title{
PENERAPAN PENDEKATAN BERMAIN UNTUK MENINGKATKAN \\ HASIL BELAJAR GERAK DASAR PERMAINAN BOLAVOLI MINI
}

\author{
Dwi Fitrianingsih ${ }^{(1)}$ Budhi Satyawan ${ }^{(2)}$

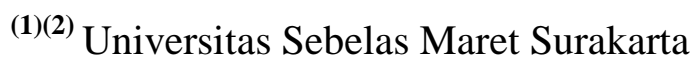

\begin{abstract}
The purpose of this research is to improve learning outcomes basic of mini volleyball with implementation play approaches to learners iv a grade of mi muhammadiyah jimbung, in the academic year 2016/2017.

This study close to practice clas action. Study held in 2 cycle consists of 4 steps in every cycle consists of planning, action, oservation and reflection. Subject in this study is learners of IV A MI Muhammadiyah Jimbung whichamounts to 22 learners, 12 male and 10 female. Data collection technique with test and observation. Data validation use triangulation data. Data analysis use descriptive qualitative with precentage tehnique.

The result are $27,27 \%$ complete and $72,72 \%$ uncomplate. This first cycle obtained resut $59,09 \%$ complate and $40,91 \%$ uncomplate with averaage value of psychomotor 59,09\%, affective $81,81 \%$ and cognitive 68,18\%. Second cycle obtained results $86,46 \%$ complate and $13,64 \%$ uncomplatewhith average value psychomotor 77,27\%, affective 90,90\%, and cognitive $81,81 \%$. Based of analysis result from 2 cyclle show increase and suitable with achievement target.

Conclusion on this study is implementation approaches can improve learning outcomes basic of mini volleyball on IV A MI Muhammadiyah Jimbung. In the academic year 2016/2017.
\end{abstract}

Keyword: learning outcomes, basic motion, mini volleyball, play approach 


\section{PENDAHULUAN}

Pendidikan jasmani merupakan suatu proses pembelajaran melalui aktivitas jasmani yang didesain untuk meningkatkan kebugaran jasmani, mengembangkan ketrampilan motorik, pengetahuan dan perilaku hidup sehat dan aktif, sikap sportif, dan kecerdasan emosi. Keberhasilan dalam pembelajaran pendidikan jasmani tidak lepas dari peran guru. Karena peran guru sangatlah penting dalam suatu pembelajaran. Kegagalan dalam mengajar memang tidak selayaknya terjadi, namun demikian ketika keadaan berbicara lain maka sudah menjadi kewajiban bagi seorang guru untuk mengadakan perbaikan atau tindakan sehingga materi yang diajarkan menjadi berhasil sesuai dengan harapan. Dalam pendidikan jasmani terdapat pembelajaran permainan bolavoli.

Permainan Bolavoli merupakan olahraga permainan bola besar yang dimainkan oleh dua tim. Masingmasing regu memiliki enam orang pemain dengan menggunakan lapangan yang berbentuk segi empat panjang dan ditengah-tengah lapangan dibentangkan pemisah yaitu net. Pendapat William G. Morgan yang dikutip oleh Agus Kristiyanto (2010 : 11) mengatakan bahwa," Bolavoli adalah permainan yang dapat dimainkan di dalam maupun di luar ruangan dengan sangat leluasa oleh banyak pemain dan tidak ada batasan jumlah pemain yang standar dalam permainan tersebut, sasarannya adalah mempertahankan bola agar tetap bergerak melewati net yang tinggi, dari satu wilayah ke wilayah lain". Oleh karena itu diperlukan ketrampilan teknik dasar bolavoli yang baik sehingga dapat memainkan bolavoli dengan efektif dan efisien.

Teknik dasar dalam permainan bolavoli adalah langkah awal dalam pembelajaran bolavoli. Pada permainan bolavoli terdapat teknik dasar di antaranya adalah passing, service, smash, dan block. Pada pembelajaran permainan bolavoli di Sekolah Dasar hendaknya dapat membentuk ketrampilan gerak dasar bagi anak-anak. Melalui berbagai ketrampilan gerak dasar akan dapat meningkatkan aktivitas 
pengembangan anak. Dengan demikian, peserta didik akan berinteraksi dengan peserta didik yang lainnya. Kesulitan dalam melakukan gerak dasar permainan menjadi salah satu permasalahan yang sering dihadapi guru maupun peserta didik dalam pembelajaran adalah peserta didik belum mengenal gerakan dasar permainan bolavoli, saat melakukan permainan bolavoli peserta didik hanya bermain dengan gerakan sebisa mereka. Kesalahankesalahan ini merupakan suatu permasalahan yang sering ditemukan pada sekolah-sekolah.

Permasalahan pembelajaran gerak dasar permainan bolavoli mini ditemukan di MI Muhammadiyah Jimbung. Berdasarkan hasil observasi menunjukkan bahwa peserta didik kelas IV A MI Muhammadiyah Jimbung secara umum memiliki hasil belajar yang rendah dalam pembelajaran gerak dasar permainan bolavoli dengan KKM 75. Dari jumlah peserta didik sebanyak 22 hanya 6 peserta didik atau $27,27 \%$ peserta didik yang mampu mencapai batas ketuntasan, sedangkan 16 peserta didik atau
$72,73 \%$ peserta didik lainnya belum mencapai ketuntasan. Hal ini disebabkan oleh model pembelajaran dan pendekatan pembelajaran yang diterapkan oleh guru masih konvensional yang menekankan pada penguasaan teknik. Dalam pembelajaran gerak dasar permainan bolavoli guru lebih menggunakan sistem pembelajaran yang pasif, dimana peserta didik kurang paham terhadap materi yang di sampaikan oleh guru dan berdampak minimnya pengetahuan. Kebanyakan peserta didik hanya bermain asal-asalan dan sebagian peserta didik khususnya perempuan hanya duduk. Hal ini berdampak munculnya rasa jenuh, bosan dan peserta didik cenderung pasif dan kurang aktif dalam pembelajaran. Serta kompetensi guru yang kurang menguasai teknik bolavoli menjadikan proses pembelajaran dari guru yang kurang menarik, mengakibatkan peserta didik tidak mencermati materi yang disampaikan. Guru hanya memberi pengarahan sebentar dan peserta didik mencontoh gerak dasar permainan bolavoli beberapa kali, kemudian peserta didik di 
instruksikan untuk bermain secara bebas. Pendekatan pembelajaran yang dilakukan guru seperti di atas merupakan salah satu faktor rendahnya hasil belajar gerak dasar permainan bolavoli peserta didik kelas IV A MI Muhammadiyah Jimbung.

Salah satu pendekatan pembelajaran yang akan diterapkan dalam mengatasi permasalahan rendahnya hasil belajar gerak dasar permainan bolavoli peserta didik kelas IV A MI Muhammadiyah Jimbung adalah pendekatan bermain. Pendekatan bermain adalah bentuk permainan yang mengaplikasikan teknik ke dalam suatu permainan atau belajar teknik suatu cabang olahraga yang dikemas dalam bentuk permainan. Dengan bermain peserta didik dapat mengembangkan fisik, mental, emosional, intelektual, dan sosial. Melalui pendekatan bermain anak diberikan kebebasan untuk mengekspresikan kemampun untuk mencapai tujuan pembelajaran. Berdasarkan permasalahan yang telah dikemukakan di atas, maka peneliti tertarik untuk melakukan penelitian pada peserta didik kelas
IV A MI Muhammadiyah Jimbung dengan judul "Penerapan Pendekatan Bermain Untuk Meningkatkan Hasil Belajar Gerak Dasar Permainan Bolavoli Mini Pada Peserta Didik Kelas IV A MI Muhammadiyah Jimbung Tahun Ajaran 2016/2017”. Diharapkan dengan adanya penelitian dengan model pembelajaran pendekatan bermain dapat meningkatkan hasil pembelajaran gerak dasar permainan bolavoli peserta didik kelas IV A MI Muhammadiyah Jimbung.

\section{METODE}

Penelitian Tindakan Kelas (PTK) ini dilaksanakan di MI Muhammadiyah Jimbung.

Teknik pengumpulan data dalam Penelitian Tindakan Kelas (PTK) ini terdiri dari : tes dan observasi.

1. Tes : digunakan untuk mendapatkan data tentang hasil belajar gerak dasar manipulatif peserta didik serta hasil tes tulis yang diberikan oleh guru.

2. Observasi : digunakan sebagai teknik untuk mengumpulkan data tentang aktivitas peserta didik 
dalam mengikuti proses belajar mengajar saat penerapan model pembelajaran meliputi data dari guru yang berupa lembar pengamatan.

Uji validitas merupakan suatu cara untuk menentukan suatu keabsahan data yang diperoleh. Dalam hal ini, untuk meningkatkan validitas data yang diperoleh, peneliti menggunakan triangulasi data.

\section{HASIL DAN PEMBAHASAN}

\section{Data Pratindakan}

Sebelum melaksanakan

proses Penelitian Tindakan Kelas, terlebih dahulu peneliti melakukan kegiatan observasi awal untuk mengetahui keadaan nyata yang ada di lapangan. Hasil kegiatan survey awal tersebuut adalah sebagai berikut:

a. Peserta didik kelas IV A MI Muhammadiyah Jimbung Tahun Ajaran 2016/2017, yang mengikuti mata pelajaran PJOK materi Bolavoli adalah 22 peserta didik, yang terdiri atas 12 peserta didik putra dan 10 peserta didik putri. Dalam proses pembelajaran PJOK materi bolavoli, masih banyak peserta didik yang kurang antusias dalam mengikuti proses pembelajaran. Terbukti dari beberapa peserta didik, ada yang berbicara sendiri dengan temannya ketika proses belajar mengajar berlangsung. Dilihat dari proses pembelajaran bolavoli, dapat dikatakan proses pembelajaran dalam kategori kurang berhasil.

b. Dilihat dari hasil wawancara kepada beberapa peserta didik kelas IV A diperoleh informasi yang variatif. Beberapa peserta didik kurang menyukai bolavoli karena malu dan takut untuk mencobanya, terutama peserta didik putri. Kebanyakan dari peserta didik putri merasa malu dan canggung dalam melakukan gerakan bolavoli. Terbatasnya media pembelajaran yang ada membuat peserta didik menjadi terhambat karena sedikitnya kesempatan mencoba saat pembelajaran yang sedang berlangsung.

c. Dari hasil observasi yang dilakukan diperoleh informasi bahwa proses belajar mengajar 
kurang efektif dan kurangnya tingkat partisipasi peserta didik dalam proses pembelajaran, karena pembelajaran hanya terpusat pada guru. Peserta didik tidak memperoleh kesempatan untuk mengembangkan keterampilan - keterampilan secara fisik, sosial, emosional, dan kognitif sangat terbatas. Pembelajaran seperti itu menjadikan anak kurang senang untuk melakukan program pendidikan jasmani karena mereka tidak mampu dan sering gagal untuk melaksanakan tugas yang diberikan. Pembelajaran yang masih konvensional tersebut terkesan monoton dan membosankan sehingga peserta didik kurang tertarik untuk mengikuti pembelajaran.

d. Dari hasil wawancara peneliti dengan guru di MI Muhammadiyah Jimbung, diperoleh data penilaian bolavoli, kelas IV A menunjukan hasil paling rendah dari jumlah 22 peserta didik hanya 6 peserta didik atau $27,27 \%$ yang mampu mencapai batas ketuntasan, sedangkan 16 peserta didik atau $72,73 \%$ peserta didik lainnya masih salah dalam menguasai gerak dasar bolavoli mini atau belum mencapai batas ketuntasan. KKM yang ditentukan MI Muhammadiyah Jimbung seperti yang telah ditetapkan dalam Peraturan BSNP (Badan Standar Nasional Pendidikan) untuk mencapai batas ketuntasan adalah 75 .

Hasil observasi antara peneliti dan guru tersebut dimaksudkan untuk mengetahui kondisi nyata keadaan kelas saat proses belajar mengajar materi bolavoli berlangsung pada kelas IV A MI Muhammadiyah Jimbung. Sebelum melakukan pelaksanaan tindakan maka peneliti dan kolabolator berkolaborasi untuk mendeskripsikan kondisi awal keadaan kelas sebelum diberikan tindakan. Adapun deskripsi data yang diambil terdiri dari: tes unjuk kerja kemampuan bolavoli (psikomotor), pemahaman konsep gerak (kognitif), pengamatan sikap (afektif) pada peserta didik kelas IV A MI Muhammadiyah Jimbung tahun pelajaran 2016/2017. 


\section{Hasil Tindakan Siklus I}

Berdasarkan data dari observasi awal yang dilakukan peneliti, peneliti menetapkan bahwa penelitian tindakan kelas yang dilakukan dengan menyusun serangkaian perencanaan.

Pembelajaran bolavoli pada siklus I tersebut dilakukan selama dua kali pertemuan. Adapun tahapan-tahapan yang dilakukan pada siklus pertama adalah sebagai berikut:

\section{Pertemuan I}

Materi pelaksanaan pada siklus I pertemuan pertama (kamis, tanggal 02 Maret 2017) adalah dengan melalui penerapan pendekatan bermain.

\section{Pertemuan II}

Materi pada pelaksanaan siklus I, pertemuan kedua ( kamis, 09 Maret 2017) adalah materi gerak dasar bolavoli dengan melalui penerapan pendekatan bermain.

Berdasarkan hasil deskripsi siklus I, hasil belajar gerak dasar permainan bolavoli mini pada peserta didik kelas IV A MI Muhammadiyah Jimbung tahun pelajaran 2016/2017 dari 6 peserta didik ( $27,27 \%)$ meningkat menjadi 13 peserta didik $(59,09 \%)$ meski belum tuntas tetapi mengalami kenaikan perolehan hasil belajarnya.

\section{Hasil Tindakan Siklus II}

Siklus II merupakan tindak lanjut dari hasil analisis dan refleksi yang dilakukan pada Siklus I, dimana dalam pelaksanaan tindakan dalam Siklus I, rata-rata peserta didik menunjukkan hasil yang kurang maksimal dan sesuai dengan kriteria yang telah ditentukan pada siklus I. Pelaksanaan Siklus II mengacu pada pelaksanaan Siklus I karena merupakan perbaikan dari Siklus I.

Tindakan siklus II dilaksanakan sebanyak 2 kali pertemuan selama 2 minggu yakni pada setiap hari Rabu tanggal 23 Maret 2017 dan 30 Maret 2017.

\section{Pertemuan I}

Materi pada pelaksanaan siklus II, pertemuan pertama (23 Maret 2017) adalah materi pembelajaran gerak dasar bolavoli mini dengan penerapan pendekatan bermain yang dapat mengembangkan keterampilan gerak, mengembangkan fisik dan kesegaran jasmani.

\section{Pertemuan II}


Materi pada pelaksanaan siklus II, pertemuan kedua (kamis, 30 Maret 2017) adalah materi pembelajaran gerak dasar bolavoli mini dengan penerapan pendekatan bermain yang dapat mengembangkan keterampilan gerak, mengembangkan fisik dan kesegaran jasmani. Hasil belajar peserta didik dalam materi pembelajaran gerak dasar bolavoli mini setelah Tindakan II dilakukan menunjukkan hasil bahwa dengan prosentase kriteria nilai sebagai berikut: Baik 9,09\%, Cukup 77,27\% , dan Kurang yaitu 13,64\%. Hal ini menunjukkan hasil yang meningkat. Sejumlah 19 peserta didik mencapai kriteria Tuntas sedangkan 3 peserta didik Belum Tuntas. Melihat hasil yang diperoleh pada Tindakan II maka penelitian tindakan kelas telah memenuhi target dari rencana yang diharapkan.

\section{Perbandingan Hasil Tindakan Antar Siklus}

Dari hasil analisis yang
diperoleh peningkatan yang
signifikan terjadi pada prasiklus ke
siklus I dan dari siklus I ke siklus II.
Pada prasiklus hasil belajar gerak

dasar permainan bolavoli mini yang tuntas adalah 6 anak 27,27\% dan 16 anak tidak tuntas $72,73 \%$, pada siklus I jumlah peserta didik yang tuntas adalah 13 anak 59,09\% dan 9 anak tidak tuntas 40,91\%. Pada siklus II jumlah peserta didik yang tuntas adalah 19 anak $86,36 \%$ dan 3 anak tidak tuntas $13,64 \%$.

\section{Pembahasan}

Berdasarkan hasil pelaksanaan tindakan pada siklus I dan II dapat disimpulkan bahwa terjadi peningkatan hasil belajar gerak dasar bolavoli mini pada peserta didik kelas IV A MI Muhammadiyah Jimbung tahun pelajaran 2016/2017. Dari hasil analisis yang diperoleh peningkatan secara signifikan terjadi pada pratindakan ke siklus I dan siklus II. Peningkatan terjadi pada siklus I dan siklus II setelah diberikan pendekatan bermain hasil belajar gerak dasar bolavoli mini meningkat pada siklus I walaupun belum optimal. Pada sikus I terdiri 8 permainan, permainan tersebut menyangkut passing, servis dan smash, dari permainan yang 
sederhana ke kompleks. Dari hasil pelaksanaan pembelajaran pada siklus I diketahui belum mencapai target ketuntasan $75 \%$ dan baru tercapai $59,09 \%$, atau peserta didik yang tuntas baru sebanyak 13 peserta didik. Meskipun secara keseluruhan menunjukkan peningkatan yang cukup, namun ada beberapa peserta didik yang kurang sungguh-sungguh dalam pembelajaran, peserta didik yang kurang mampu dalam mempraktikkan gerak dasar bolavoli mini dengan baik, kecurangan dalam permainan, lupa dengan gerakan yang telah diajarkan oleh guru, permainan yang kurang menarik sehingga peserta didik merasa jenuh, dan peserta didik kurang aktif menanyakan kesulitan dalam pembelajaran. Sehingga dilaksanakan siklus II berdasarkan refleksi siklus I.

Pada siklus II terdiri dari 3 permaninan tetapi permainan tersebut kompleks. Pelaksanaan siklus II menyebabkan hasil belajar gerak dasar bolavoli mini meningkat menjadi lebih baik dan tercipta proses pembelajaran yang lebih aktif, efektif dan menyenangkan sehingga bisa menudukung suatu proses pembelajaran yang berkualitas. Karena dengan menerapkan pendekatan bermain yang bervariasi, permainan yang lebih kompleks dan menantang pada proses pembelajaran peserta didik lebih antusias, timbul rasa semangat dan menarik bagi peserta didik untuk berkompetisi secara jujur. Sehingga peserta didik tidak mudah bosan dalam pembelajaran gerak dasar bolavoli mini. Hal tersebut berdampak pada peningkatan hasil belajar gerak dasar bolavoli mini pada peserta didik kelas IV A MI Muhammadiyah Jimbung. Terlihat bahwa rata-rata setiap peserta didik mengalami peningkatan, hal tersebut menandakan bahwa peserta didik memberikan respon positif terhadap penerapan pendekatan bermain. Sehingga pada siklus II target ketuntasan $75 \%$ dapat tercapai batas melebihi target tersebut yaitu sebesar $86,36 \%$ atau sebanyak 19 peserta didik.

SIMPULAN, IMPLIKASI DAN SARAN

simpulan 
Penelitian Tindakan Kelas pada peserta didik kelas IV A MI Muhammadiyah Jimbung tahun pelajaran 2016/2017 dilaksanakan dalam dua siklus. Setiap siklus terdiri atas empat tahapan, yaitu: (1) perencanaan, (2) pelaksanaan tindakan, (3) observasi dan interpretasi, dan (4) analisis dan refleksi. Dari hasil analisis diperoleh peningkatan yang singnifikan dari pra siklus ke siklus I dan dari siklus I ke siklus II. Hal ini telah terlihat dari hasil tes unjuk kerja dari studi awal, dari 22 peserta didik yang pada awalnya mendapatkan ketuntasan 6 peserta didik $27,27 \%$ dan belum tuntas 16 peserta didik belum tuntas 72,73\%. Pada siklus I hasil belajar peserta didik mencapai kriteria tuntas pada siklus I sebanyak 59,09\% atau 13 peserta didik. Pada siklus II hasil belajar peserta didik meningkat mencapai 86,36\% atau sebanyak 19 peserta didik telah mencapai kriteria tuntas sedangkan 3 peserta didik lainnya belum tuntas diberikan remidial sampai peserta didik tersebut tuntas.

Dengan demikian dapat disimpulkan bahwa, pembelajaran melalui penerapan pendekatan bermain dapat meningkatkan hasil belajar gerak dasar bolavoli mini pada peserta didik kelas IV A MI Muhammadiyah Jimbung tahun pelajaran 2016/2017.

\section{Implikasi}

Berdasarkan simpulan penelitian yang telah dikemukakan di atas, maka dapat diketahui bahwa pembelajaran gerak dasar bolavoli mini melalui penerapan pendekatan bermain dapat meningkatkan hasil belajar gerak dasar bolavoli mini pada peserta didik kelas IV A MI Muhammadiyah Jimbung tahun pelajaran 2016/2017. Dengan demikian, implikasi penelitian tindakan kelas ini adalah:

1. Penelitian ini memberikan suatu gambaran yang jelas bahwa keberhasilan proses pembelajaran tergantung pada beberapa faktor. Faktor-faktor tersebut berasal dari pihak guru maupun peserta didik serta model pembelajaran yang di berikan. Faktor dari pihak guru yaitu kemampuan guru dalam mengembangkan materi, kemampuan guru dalam menyampaikan materi, 
kemampuan guru dalam mengelola kelas, metode yang digunakan guru dalam proses pembelajaran, pendekatan pembelajaran yang tepat sesuai materi ajar, serta teknik yang digunakan guru sebagai sarana untuk menyampaikan materi. Sedangkan faktor dari peserta didik yaitu minat dan motivasi peserta didik dalam mengikuti pembelajaran.

2. Memberikan deskripsi yang jelas bahwa dengan penerapan pendekatan bermain dapat meningkatkan hasil belajar gerak dasar bolavoli mini, sehingga penelitian ini dapat digunakan sebagai suatu pertimbangan bagi guru penjas untuk meningkatkan keterampilan bolavoli peserta didik dalam olahraga permainan lainya dengan penerapan pendekatan bermain khususnya pada olahraga permainan.

3. Penerapan pendekatan bermain untuk meningkatkan hasil belajar belajar gerak dasar bolavoli mini peserta didik, sehingga peserta didik memperoleh pengalaman baru dan berbeda dalam proses pembelajaran penjasorkes biasanya. Pembelajaran Penjasorkes yang pada awalnya membosankan bagi peserta didik, menjadi pembelajaran yang menarik dan menyenangkan bagi peserta didik .

4. Penerapan pendekatan bermain terbukti dapat meningkatkan hasil belajar gerak dasar bolavoli mini peserta didik dalam pelajaran penjasorkes maka mempengaruhi pula hasil belajar peserta didik secara keseluruhan sehingga meningkatkan kualitas sekolahan tersebut.

5. Penerapan pendekatan bermain menjadikan peserta didik lebih aktif dalam pembelajaran.

\section{Saran}

Sesuai dengan simpulan dan implikasi hasil penelitian tindakan kelas yang telah diungkapkan diatas, serta dalam rangka upaya bagi guru dalam meningkatkan penguasaan beljar, khususnya bidang studi penjasorkes, maka dapat disampaikan saran-saran sebagai berikut: 
1. Bagi peserta didik kelas IV A MI Muhammadiyah Jimbung

a. Melalui penerapan pendekatan bermain peserta didik dapat meningkatkan kompetisi materi pembelajaran gerak dasar bolavoli mini sehingga hasil belajar yang diperoleh semakin meningkat.

2. Bagi guru pendidikan jasmani, olaraga dan kesehatan di MI

Muhammadiyah Jimbung

a. Kepada guru hendaknya menerapkan model pembelajaran dengan menggunakan pendekatan bermain agar peserta didik dapat dengan mudah memahami pelajaran dan aktif dalam proses pembelajaran, karena dengan menggunakan pendekatan bermain dapat menarik peserta didik untuk berpartisipasi aktif dalam mengikuti pembelajaran. b. Guru hendaknya terus berusaha untuk meningkatkan kemampuannya dalam mengembangkan materi, menyampaikan materi, serat mengelola kelas, sehingga kualitas pembelajaran yang dilakukannya dapat terus meningkat seiring kemampuan yang dimilikinya.

c. Guru hendaknya mau membuka diri untuk menerima berbagai bentuk masukan, saran, dan kritikan agar dapat lebih memperbaiki kualitas mengajarnya. 


\section{DAFTAR PUSTAKA}

Agus Kristiyanto. (2010). PenelitianTindakanKelas (PTK). Surakarta: UNS Press.

Agus Kristiyanto. (2010). Memperluas Desain Permainan Bolavoli di Masyarakat kita. Surakarta: UNS Press.

Agus Mukholid dan Budhi Satyawan. (2009). Aktivitas Luar Kelas. Surakarta: UNS Press.

Aunurrahman. (2009). Belajar dan Pembelajaran. Bandung: Alfabeta

Deni Kurniawan (2014). Pembelajaran Terpadu Tematik. Bandung: Alfabeta

Dimyati dan Mudjiono. (2009). Belajar Dan Pembelajaran. Jakarta: Departemen Pendidikan Dan Kebudayaan.

Ma'mun, A dan Saputra, Y.M. (2006). Perkembangan Gerak dan Belajar Gerak. Jakarta: Departemen Pendidikan dan Kebudayaan.

Moh. Suardi. (2015). Belajar dan Pembelajaran. Diperoleh 18 Desember 2016. Pukul 18.35 dari Yog https://ilmu-pendidikan.net/pembelajaran/ciri-ciribelajar

Oemar Hamalik. (2009). Kurikumlum dan Pembelajaran. Sinargrafika: Jakarta.

Purwanto. (2008). Evaluasi Hasil Belajar. Surakarta:Pustaka Belajar.

Slameto. (2009). Belajar dan Faktor-Faktor yang Mempengaruhi. Jakarta: PT Rineka Cipta

Sudjana. (1990). Penilaian Hasil Proses Belajar Mengajar. Bandung: Sinar Baru Suharna. (1974). Dasar-dasar pemaianan bolavolley. Yogyakarta: UGM Press Sunardi dan Deddy Whinata. (2013). Bolavoli. Surakarta: UNS Press 